\title{
Profile of blood donors who presented adverse reactions to the donation
}

\author{
Perfil dos doadores de sangue que apresentaram reações adversas à doação \\ Perfil de los donantes de sangre que presentaron reacciones adversas a la donación
}

\author{
Melissa Orlandi Honório Locks' \\ ORCID: 0000-0003-0972-2053 \\ Nádia Chiodelli Salum' \\ ORCID: 0000-0002-2624-6477 \\ Beatriz Steingreber de Barros' \\ ORCID: 0000-0001-7104-0446 \\ Eliane Matos' \\ ORCID: 0000-0002-5105-870X \\ Jane Cristina Anders' \\ ORCID: 0000-0002-9130-1073 \\ Dulcinéia Ghizoni Schneider' \\ ORCID: 0000-0002-4842-2187
}

'Universidade Federal de Santa Catarina. Florianópolis, Santa Catarina, Brazil.

How to cite this article: Locks MOH, Salum NC, Barros BS, Matos E, Anders JC, Schneider DG. Profile of blood donors who presented adverse reactions to the donation. Rev Bras Enferm [Internet]. 2019;72(1):81-7. DOI: http://dx.doi.org/10.1590/0034-7167-2018-0305

Corresponding Author: Melissa Orlandi Honório Locks E-mail: melhonorio@hotmail.com

Submission: $05-18-2018$

Approval: 07-10-2018

\begin{abstract}
Objective: identify the adverse reactions presented by blood donors and outline their sociodemographic profile. Method: a quantitative, cross-sectional retrospective study of 780 records of blood donors from a public hemocenter in the southern region of Brazil, from December 2015 to January 2016. For the analysis the descriptive statistics was used. Results: it was identified that throughout 12 months, the total blood donors corresponded to 27,300 people, in which 780 developed at least one reaction. They were characterized by female and recurrent donors, single, with a complete average level of education, ranging from 16 to 30 years, who triggered between 1 and 3 reactions. Mild reactions were more frequent, followed by moderate and severe reactions. Conclusion: There is a high rate of adverse reactions from donors emphasizing the need for changes in hemotherapy care practices.

Descriptors: Blood Donors; Hemotherapy Service; Patient Safety; Blood Bank; Nursing.
\end{abstract}

\section{RESUMO}

Objetivo: identificar as reações adversas apresentadas pelos doadores de sangue e traçar o seu perfil sociodemográfico. Método: pesquisa quantitativa, retrospectiva transversal, realizada em 780 registros de doadores de sangue de um hemocentro público da região sul do Brasil, no período de dezembro de 2015 a janeiro de 2016. Para análise procedeu-se à estatística descritiva. Resultados: identificou-se que, no período de 12 meses, o total de doadores de sangue correspondeu a 27.300 pessoas, no qual 780 desenvolveram ao menos uma adversidade. Caracterizaram-se por doadores de repetição, do gênero feminino, solteiros, com nível de escolaridade médio completo, na faixa etária de 16 a 30 anos, que desencadearam entre 1 e 3 adversidades. As reações leves foram mais recorrentes, seguidas das reações moderadas e graves. Conclusão: Aponta-se um alto índice de reações adversas por parte dos doadores enfatizando a necessidade de mudanças nas práticas dos cuidados em hemoterapia.

Descritores: Doadores de Sangue; Serviço de Hemoterapia; Segurança do Paciente; Bancos de Sangue; Enfermagem.

\section{RESUMEN}

Objetivo: identificar las reacciones adversas presentadas por los donantes de sangre y trazar su perfil sociodemográfico. Método: una investigación cuantitativa, retrospectiva transversal, realizada en 780 registros de donantes de sangre de un hemocentro público de la región sur de Brasil, en el período de diciembre de 2015 a enero de 2016. Para el análisis se procedió a la estadística descriptiva. Resultados: se identificó que, en el período de 12 meses, el total de donantes de sangre correspondió a 27.300 personas, en el cual 780 desarrollaron al menos una adversidad. Se caracterizaron por donantes de repetición, del género femenino, solteros, con nivel de escolaridad promedio completo, en el grupo de edad de 16 a 30 años, que desencadenaron entre 1 y 3 adversidades. Las reacciones lleves fueron más recurrentes, seguidas de las reacciones moderadas y graves. Conclusión: se señala un alto índice de reacciones adversas por parte de los donantes enfatizando la necesidad de cambios en las prácticas de los cuidados en hemoterapia.

Descriptores: Donantes de Sangre; Servicio de Hemoterapia; Seguridad del Paciente; Bancos de Sangre; Enfermería. 


\section{INTRODUCTION}

Currently, studies of multidimensional knowledge of the demographic profile of a given population are characterized as extremely important actions. These studies make it possible for health problems to be detected, regardless of the condition and degree of interference, so that appropriate action can be taken by recognizing the characteristics of the population and the factors that may interfere in the perception and action of the agents involved ${ }^{(1)}$.

In national blood banks, this recognition becomes relevant since voluntary donors may present adverse reactions, which vary in severity according to their degree of intensity. Donation is characterized as a voluntary and altruistic act, free of any benefit or reward. The permanence of donors in the donation cycle is also influenced by the attention they receive in the health service, which contributes to the maintenance of hemocenters stocks, to guarantee the full demand response demanded by the specific and emerging needs of health units ${ }^{(2)}$.

In view of the increasingly emerging demands, blood donations do not meet the needs of transfusions in health services ${ }^{(3)}$. Many countries face obstacles to supply the demand for blood, especially those where there is a policy that prohibits their commercialization, like Brazil. National data show only $2 \%$ of the population as blood donors, while the Ministry of Health recommends an approximation of $3 \%$ to $5 \%$, justifying an even greater effort to attract and retain these donors ${ }^{(4)}$.

Donations are usually simple and safe and occur without any type of complications or clinical complications. However, despite all the care taken to protect volunteers when donating, donors may occasionally experience adverse events in the process. Thus, donors should be assisted by a trained nursing team to be able to detect early adverse reactions and their complications ${ }^{(4)}$.

Therefore, even in the face of technological advances, donor care becomes indispensable in order to avoid or minimize the occurrence of adverse reactions. It is known that in most national blood centers, the reception, blood collection and post-donation recommendations are performed by a nursing team composed of auxiliaries, technicians and nurses. The competencies and attributions of these professionals are established and supported by the Federal Nursing Council Resolution (Conselho Federal de Enfermagem) No. 511/2016, which approves the technical standard that deals with the work of nurses and nursing technicians in hemotherapy ${ }^{(5)}$ and by Regulation No. $158 / 2016^{(2)}$, which redefines the technical regulation of hemotherapy procedures, both with the purpose of regulating these activities in the country, according to the principles and Guidelines of the National Policy of Blood and Hemoderivatives (Diretrizes da Política Nacional de Sangue e Hemoderivados). It is hoped, therefore, that since the reception of the donor, the professionals involved in the process will be able to identify at an early stage possible predisposition to reactions, with a view to developing strategies for immediate decision making, to guarantee the safety and integrity of this donor. In addition, through current and real data, it will be possible to provide reliable information about the best practices to be offered to the clientele, to direct care and to allow a better understanding of the consultations carried out in the various contexts of the institutions involved in the blood donation process. The history of Brazilian hemotherapy over the last 30 years has recorded important advances in the search for a hemotherapy system that offers the population a final product with safety and quality. This was possible thanks to the restructuring of services, legitimation of blood donation as a voluntary, altruistic and unpaid act, as well as technological advances, legislation, technical regulations, training and modernization of management. The national public hemonet, in this context, ended up with the task of guaranteeing the blood supply to the whole population in a safe and sustainable way, seeking the selection of candidates for healthy, voluntary and regular donations ${ }^{(6)}$. In Brazil, the regulation of Hemotherapy is carried out by the National Sanitary Surveillance Agency (ANVISA), which initially regulated, through the Resolution of the Collegiate Board of Directors (Resolução da Diretoria Colegiada) No. 153 of June 14, 2004, standardization of hemotherapy procedures, including those for collection, processing, testing, storage, transport and use as a means of ensuring blood quality ${ }^{(7)}$. Today, after some revisions, this regulation is available through $R D C$ No. 2.712, of November $12,2013^{(8)}$. According to this resolution, the technical regulation of hemotherapy procedures is redefined, and its Article 78 states that hemotherapy services that perform blood collection must be prepared for the treatment of adverse reactions from donations. The resolution further describes that the following criteria should be observed: 1) the existence of operational procedures with specific instructions for the prevention, identification and treatment of adverse reactions in donors; 2) the availability of medication and equipment necessary to provide medical assistance to the donor that presents adverse reactions; 3 ) the guarantee of privacy for the care of the donor in case of need; and 4) record keeping of adverse reactions to donations. In this context, hemotherapy services should implement programs designed to minimize risks to donor's health, ensuring their safety. Donors records should be kept ensuring the safety of the blood donation process and its traceability. In addition, the blood collection procedure should ensure the safety of the donor and of any donation process, in which the blood collection procedure must be performed by trained professionals working under the supervision of a nurse or a doctor ${ }^{(8)}$.

Blood donation is safe and, in general, donors put up with the procedure well, but may have adverse reactions to the donation. These can be quickly recognized and dealt with, as this is limited to their intensity and, consequently, to their consequences ${ }^{(8)}$.

Thus, at present, much is discussed about transfusion of blood components and blood products followed by their transfusion reactions, but little is actually described about the donation of these blood components and their reactions.

Thus, the prompt action of the nursing team is important, since the occurrence of adverse reactions to the donation leads to a negative impact on the intention of new donations. To do this, those who work directly with these voluntary donors must know how to recognize the adverse reactions, provide them with the first care, so that they are able to handle the urgency equipment and materials that must be available in the department. They should also remain with the donor, being able to perform 
the initial care and refer them to the medical evaluation when indicated $^{(8)}$.

Therefore, it is up to nurses of the hemotherapy services to know this potential population, as well as to encourage their staff to perform a systematized care. To this end, it is necessary to motivate and promote the continuing education of its team, favoring the dissemination of public policies to encourage voluntary blood donation, becoming one of the references in the elaboration of strategies capable of sensitizing society ${ }^{(9)}$.

Considering the above, this study started with the following questions: what are the adverse reactions and the sociodemographic profile of blood donors?

\section{OBJECTIVE}

Identify the adverse reactions presented by blood donors and outline their sociodemographic profile.

\section{METHOD}

\section{Ethical aspects}

The ethical aspects of research were respected following the guidelines of Resolution No. 466, of December 12, 2012, of the National Health Council ${ }^{(10)}$, being approved by the Research Ethics Committee of the Hematology and Hemotherapy Center of Santa Catarina - CEP/HEMOSC.

\section{Research design, place and period}

Quantitative, retrospective, cross-sectional study performed at a public hemocenter of southern Brazil (HEMOSC). To that end, data collection conducted between December 2015 and January 2016 used the records of the institution's database for donations that occurred between January 1 and December 31, 2014 as a source of information.

\section{Population, sample, inclusion and exclusion criteria}

During the data collection period, 27,300 blood donors were registered. For the composition of the sample of this study the records that met the eligibility criteria were chosen donors with some adverse reaction, at any stage of the donation of whole blood. The records of donors that presented adverse reactions occurred in the donation of blood components by apheresis and accidents from phlebotomy were excluded. The final sample consisted of 780 records.

Access to information was performed through the analysis of the collection reaction report, and allowing to compile the reactions presented in 2014 and the degree of severity, as well as gender, age, marital status, educational level and number of donations made by these affected donors, number of adverse events recorded and severity of reactions.

\section{Study protocol}

Initially, a retrospective search was conducted through an active search in HEMOSIS donor records. Research aimed to identify the adverse reactions presented by blood donors, registered in 2014 - from January 1 to December 31, 2014. Such information is available in the internal computerization system of HEMOSC, HEMOSIS.

This step aimed to identify the profile of voluntary donors to blood donations that present adverse reactions.

From the records in the HEMOSIS database, information belonging to each HEMOSC donor was sought, regarding the profile of those who presented adverse reactions during donation, subsequently quantifying the adverse reactions that were predominantly described in the year 2014. These profiles included data such as sex, age, marital status, educational level, number of donations and number of reactions presented.

The Reaction Collection Report - Detailed, available on the RCDS5136 screen was consulted monthly. Through it, it was possible to identify each donor and each reaction presented by it in that month of donation.

Once data had been collected, CDS1020 Screen "Donor Identification" followed, and it was possible to collect and compile data regarding sex, age, educational level, number of donations and reactions presented by these donors. The data was organized in spreadsheets of Excel ${ }^{\circ}$ for Windows ${ }^{\circ}$ program, quantified and evaluated according to their specificity.

\section{Analysis of results}

Data was inserted monthly, allowing the variables to design the profile of donors most affected by adverse reactions, allowing the identification of the monthly relative number of these reactions.

The analysis of data was done through simple descriptive statistics, with absolute and relative numbers in each variable, by the Sestatnet platform ${ }^{(11)}$.

With the survey of the adverse reactions registered in 2014 in HEMOSIS, the objective was to design the profile of donors most susceptible to adverse reactions in donations of whole blood, using simple statistical analysis, by means of the absolute and relative calculation of the data found.

\section{RESULTS}

From the records of 27,300 total blood donors in 2014, it was shown that 780 of these presented adverse reactions. Blood donor profile data from HEMOSC is shown in Table 1, which follows:

Regarding the sociodemographic aspects of the 780 blood donors in 2014, results showed that the injuries occurred mostly in the female sex (66\%), whereas 474 (60.77\%) declared themselves unmarried; 285 (36.54\%) had completed an average level of education; the majority (64.49\%) belonged to the age group of 16 to 30 years. As for the occurrence of reactions, $66 \%$ developed between 1 and 3 reactions.

Concerning the analysis of the number of donations, 357 (45.77\%) donors had between 2 and 5 donations of blood in their history and 325 (41.67\%) were donating blood for the first time in 2014.

The number of adverse reactions was analyzed monthly during the year studied, according to Figure 1, highlighting July as the month with the highest number of adverse reactions. 
Table 1 - Profile of blood donors who presented adverse reactions to donation in 2014, Florianópolis, Santa Catarina, Brazil, 2016

\begin{tabular}{|c|c|}
\hline Epidemiological Data & n (\%) \\
\hline \multicolumn{2}{|l|}{ Sex } \\
\hline M & $267(34)$ \\
\hline $\mathrm{F}$ & $513(66)$ \\
\hline \multicolumn{2}{|l|}{ Marital Status } \\
\hline Single & $474(60.77)$ \\
\hline Married & $205(26.28)$ \\
\hline Stable union & $85(10.9)$ \\
\hline Divorced & $14(1.8)$ \\
\hline Widower & $2(0.26)$ \\
\hline \multicolumn{2}{|l|}{ Level of Education } \\
\hline Undergraduate Degree & $163(20.9)$ \\
\hline Incomplete Undergraduate Degree & $201(25.77)$ \\
\hline High School & $285(36.54)$ \\
\hline Incomplete High School & $63(8.08)$ \\
\hline Basic Level & $20(2.56)$ \\
\hline Incomplete Basic Level & $10(1.28)$ \\
\hline Specialization & $29(3.72)$ \\
\hline Master's Degree & $3(0.38)$ \\
\hline Doctor's Degree & $1(0.13)$ \\
\hline Not informed & $5(0.64)$ \\
\hline \multicolumn{2}{|l|}{ Age Range } \\
\hline $16-30$ years old & $503(64.49)$ \\
\hline $31-45$ years old & $225(28.85)$ \\
\hline $46-69$ years old & $52(6.67)$ \\
\hline \multicolumn{2}{|l|}{ No of Adverse Reactions } \\
\hline 1 to 3 reactions & $515(66.02)$ \\
\hline 4 to 6 reactions & $247(31.67)$ \\
\hline 7 to 10 reactions & $18(2.31)$ \\
\hline \multicolumn{2}{|l|}{ No of Donations } \\
\hline $1^{\text {st }}$ donation & $325(41.67)$ \\
\hline 2 to 5 donations & $357(45.77)$ \\
\hline 6 to 10 donations & $73(9.36)$ \\
\hline 11 to 15 donations & $15(1.92)$ \\
\hline Above 15 donations & $10(1.28)$ \\
\hline Total & $780(100)$ \\
\hline
\end{tabular}

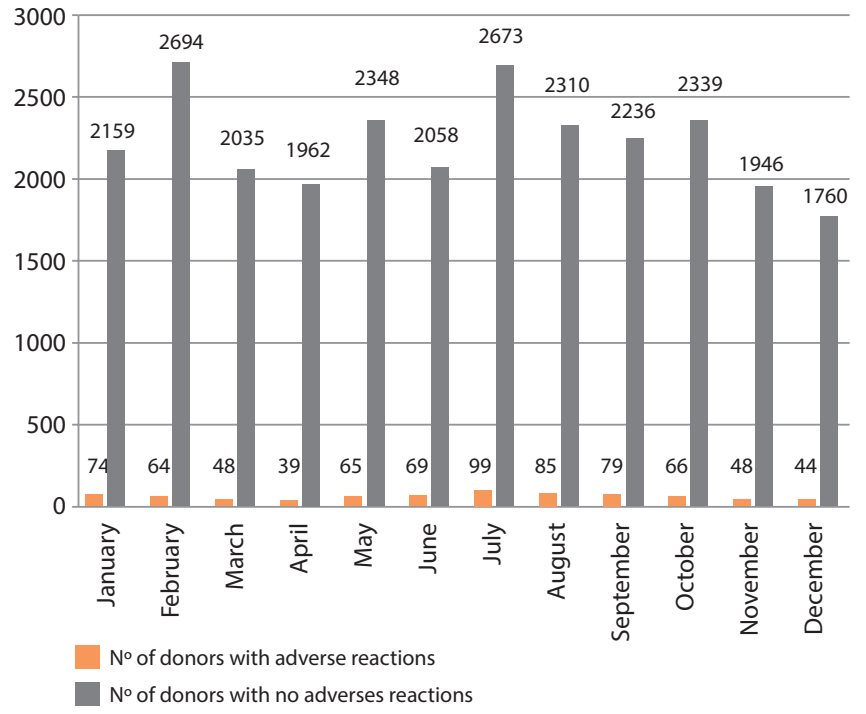

Source: Database of HEMOSC (2016)

Figure 1 - Distribution of blood donations and their relation with the occurrence of adverse reactions in 2014, Florianópolis, Santa Catarina, Brazil, 2016

Regarding the severity of the reactions identified, Table 2 and 3 represent, respectively, the adversities classified by the health service studied as mild and moderate. These adverse events are presented in a monthly chronological order and are arranged in alphabetical order.

The reactions considered to be severe were manifested in 68 episodes, and those with the highest incidence were: skin and mucosal cyanosis $(5.89 \%)$, mental confusion $(4.41 \%)$, muscle spasms (38.23\%), loss of consciousness $(42.65 \%)$, sphincter relaxation $(2.94 \%)$, tachycardia $(1.47 \%)$, tachypnea $(1.47 \%)$ and episodes of tetany, corresponding to $2.94 \%$. Mild reactions predominated among the types of reactions identified, with a total of $1,385(56.85 \%)$ adversities presented in 2014, which corresponds to an average of 115 reactions per month. Moderate reactions followed, with a percentage of $40.35 \%$ and severe reactions, with $2.8 \%$ of complications.

Source: Database of HEMOSC (2016)

Table 2 - Mild Reactions Presented in 2014, Florianópolis, Santa Catarina, Brazil, 2016

\begin{tabular}{|c|c|c|c|c|c|c|c|c|c|c|c|c|}
\hline Reactions & Jan. (n) & Feb. (n) & Mar. (n) & Apr. (n) & May. (n) & Jun. (n) & Jul. (n) & Aug. (n) & Sep. (n) & Oct. (n) & Nov. (n) & Dec. (n) \\
\hline Anxiety & 11 & 12 & 11 & 8 & 7 & 8 & 13 & 8 & 16 & 5 & 5 & 8 \\
\hline Dry Mouth & 3 & & 1 & 2 & & & 2 & & & & & \\
\hline General Tingling & & & & & & 1 & & & 1 & & & \\
\hline Local Tingling & & 1 & & & & & 1 & & 1 & & 1 & \\
\hline Weakness & 18 & 13 & 13 & 10 & 21 & 14 & 27 & 26 & 19 & 26 & 9 & 9 \\
\hline Cold & 1 & 4 & & & 1 & 3 & 2 & 1 & 2 & 1 & 1 & 1 \\
\hline Nervousness & 9 & 8 & 7 & 8 & 6 & 5 & 16 & 7 & 7 & 5 & 6 & 9 \\
\hline $\begin{array}{l}\text { Paresthesia of } \\
\text { Extremities }\end{array}$ & & & 1 & & & & & & 1 & & 1 & \\
\hline Perioral Paresthesia & & & & & 1 & & & & & & 1 & \\
\hline Sweating & 27 & 30 & 18 & 18 & 19 & 28 & 43 & 35 & 28 & 26 & 15 & 18 \\
\hline Dizziness & 65 & 49 & 42 & 33 & 55 & 50 & 87 & 75 & 57 & 56 & 32 & 33 \\
\hline TOTAL(n) & 134 & 117 & 93 & 79 & 110 & 109 & 191 & 152 & 132 & 119 & 71 & 78 \\
\hline (\%) & 9.68 & 8.45 & 6.7 & 5.70 & 7.94 & 7.87 & 13.8 & 11 & 9.53 & 8.6 & 5.1 & 5.63 \\
\hline
\end{tabular}

Source: Database of HEMOSC (2016). 
Table 3 - Moderate Reactions Presented in 2014, Florianópolis, Santa Catarina, Brazil, 2016

\begin{tabular}{|c|c|c|c|c|c|c|c|c|c|c|c|c|}
\hline Reactions & Jan. (n) & Feb. (n) & Mar. (n) & Apr. (n) & May. (n) & Jun. (n) & Jul. (n) & Aug. (n) & Sep. (n) & Oct. (n) & Nov. (n) & Dec. (n) \\
\hline Headache & 2 & & 1 & & & & 2 & 1 & 2 & & 1 & \\
\hline Epigastric Pain & & & & & & & 1 & 2 & 1 & & 2 & \\
\hline Arterial Hypertension & 7 & 7 & 2 & 6 & 5 & 2 & 3 & 7 & 2 & & 1 & 1 \\
\hline Nausea & 16 & 15 & 7 & 11 & 20 & 20 & 21 & 23 & 12 & 13 & 11 & 12 \\
\hline Pallor & 62 & 53 & 42 & 32 & 54 & 57 & 81 & 73 & 65 & 56 & 31 & 37 \\
\hline Period of Unconsciousness & 5 & 4 & 1 & 3 & 5 & 7 & 3 & 6 & 3 & 3 & 6 & 2 \\
\hline Fall to the Ground & & 2 & 1 & & 1 & 1 & & & 2 & & 1 & \\
\hline Muscle Tremors & 4 & 1 & 2 & & 2 & 3 & 3 & 4 & & 1 & 1 & \\
\hline Vomiting & 4 & 1 & 1 & & & 3 & 3 & 3 & 3 & 2 & 3 & 1 \\
\hline Total (n) & 100 & 83 & 57 & 52 & 87 & 93 & 117 & 119 & 90 & 75 & 57 & 53 \\
\hline$\%$ & 10.2 & 8.4 & 5.8 & 5.3 & 8.8 & 9.5 & 11.9 & 12.1 & 9.2 & 7.6 & 5.8 & 5.4 \\
\hline
\end{tabular}

Source: Database of HEMOSC (2016).

\section{DISCUSSION}

The population predominantly affected by adverse events, in a hemocenter coordinator of the public network of blood banks of the southern region of Brazil, in 2014, was characterized by having female donors, with ages ranging from 16 to 30 years old.

It is justified to consider the ages of 16 and 17 in the present study given that the current Resolution No. 158/16, which regulates hemotherapy procedures, makes it possible, among other criteria, to donate blood while being between 16 and 69 years old ${ }^{(4)}$.

Corroborating these findings, a study carried out in the blood bank of the Hematological Foundation of Colombia (Fundação Hematológica da Colômbia) $)^{(12)}$ points out that the clientele susceptible to adverse reactions corresponds to female donors (65.9\%), with a mean age of 27 .

On the other hand, the data found in another study, carried out in a hemocenter of the Triângulo Mineiro ${ }^{(9)}$, show that there is no gender distinction in the adverse reactions. According to the study, the difference between the development of injuries for male and female donors was $2.2 \%$, that is, data not very expressive when compared to the findings of this research, $32 \%$. It is clear, however, that this proportion may vary according to the service demand, since this specialty is in force through continuous campaigns and specific strategies for engaging the population in the donation cycle.

As to the gender of the predominant public to the donation, a study ${ }^{(9)}$ does not reveal or distinguish between genders. However, as in the hemocenter of Santa Catarina State, HEMOPA - Hemocenter of Pará State, has mostly male donors. This representation was also evidenced in Santa Catarina, in 2014, when the state estimated about $56 \%$ of male donors. The state of Pará points out that the male public is characterized by $80 \%$ of total blood donations ${ }^{(13)}$.

Regarding the age group of donors, one study ${ }^{(9)}$ shows that the younger clientele tends to develop more adverse reactions than the other ages. According to the authors, these values correspond to $68.5 \%$ of the reactions presented, similar to that found in this study of $64.4 \%$, aged between 16 and 30 . This data points us to the possible relation with this age group, considering that younger people are those who make more blood donations, therefore, more likely to develop reactions.
The variation existing between the ages of 16 and 18 years old was based on several updates of Resolution No. 158/16, which redefines the technical regulation of hemotherapy procedures in the country and allows volunteers aged between 16 and 69, 11 months and 29 days can be candidates for donation ${ }^{(6)}$.

As for donors' marital status, a study carried out in the Triângulo Mineiro $^{(9)}$ demonstrated that $62 \%$ were single, whereas $28 \%$ were married. When compared to the results presented in the present study, it is observed that the values approach expressively, in Santa Catarina State, in 2014: 474 donors (60.77\%) declared themselves single, whereas 205 (26.28\%) said they were married.

In a study carried out in Cuban blood centers, it is suggested that there is an association of adverse reactions with the level of knowledge of donors, generally differentiated by their general sociocultural aspects. These blood centers present as a proposal to minimize such occurrences that all donors are very well advised as to the procedures to be performed and always questioned about their main doubts, fears, yearnings and anxieties about all the mysticism that donation involves ${ }^{(12)}$.

Under this perspective, it was observed that donors of the HEMOSC network, highlighted for developing donation effects, were identified with satisfactory levels of education. The Santa Catarina volunteers accounted for $87.44 \%$ of those with educational level equal to or higher than high school level. However, there are no studies that point out which guidelines are given to donors, given the little impact of these guidelines to minimize adverse reactions and repeat donors. In a study carried out in Basic Health Units of Bahia State, it was evidenced that nurses are able to establish a more horizontal relationship with donors from the reception, sensitive listening, dialogue and orientations, to showing interest in the complaints of them, a fact that contributes to the establishment of the link with donors ${ }^{(14)}$.

In a study conducted in Nigeria, the authors point out that blood donors with higher education levels are predominant. They argue that the "donating blood" culture comes from a higher prevalence of better educated donors, justifies such a public as the one with the most access to information and, therefore, the willingness to help others by developing fewer adverse reactions ${ }^{(15)}$.

Regarding the number of donations related or not related to the presentation of adverse reactions, a study in Germany cites that the first-time donors represented the population most 
affected by adverse reactions, unlike the repeat donors, who suffered less ${ }^{(16)}$. This data diverges, in part, from those found in the Santa Catarina blood bank, once $45.77 \%$ of the donors who had already performed 2 to 5 donations were the most affected by reactions, followed by the approximate number of first-time donors estimated at $41.67 \%$. However, these findings corroborate the results of a study conducted in Indian tertiary care hospitals when they say that repeat donors are the most adversely affected by donating blood(5).

Blood donation, although safe, has some potentially avoidable complications associated with it, important reasons for donors' failure to return for repeat donations. Based on the data collected in this study, 27,300 blood donors were described and, of these, 780 had one or more reactions in the donation, a value that comprises approximately $2.85 \%$ of the donors. Corroborating this finding, a survey conducted in Minas Gerais State for 2 years (from 2009 to 2011) found that adverse reactions to blood donation may vary from hemocenter to hemocenter. Nevertheless, the average of adverse reactions presented by donors of whole blood is present at about $3 \%^{(9)}$. In Cuban blood centers, such adversities occur from 2 to $5 \%{ }^{(12)}$.

Even though the incidence of adverse reactions among blood donors varies according to different studies, they account for about $1 \%$ of all donations. This alternation may exist due to the different natures of the studies, observer threshold, environmental conditions, studied heterogeneous population and racial differences ${ }^{(3)}$. As for the seasons, we can identify that the highest rates of adverse reactions in this study occurred during winter, disagreeing with research carried out in which the blood collections, the targets of its study, were carried out in open air fields in Mumbai, where the weather is hot and humid during most months of the year. Thus, adverse events were observed more frequently during the afternoons, when the temperature was higher and when there was agglomeration and concentration of donors. As strategies to reduce adverse reactions, the intake of liquids was encouraged half an hour before blood donation ${ }^{(17)}$.

This information also supports information in a study developed in India, in which a significantly greater number of general complications as well as vasovagal reactions were observed in March and April compared to the previous two months. The probable reason for this fact is because these are months in which the temperature at this time is higher when compared to other months. This could lead to increased sweating and loss of body volume, contributing to the dehydration of donors and greater chances of developing reactions and associated complications ${ }^{(3)}$.

In the state of Santa Catarina, the season with the greatest reaction was winter, probably due to the fact that there were more blood donations when compared to the rest of the year, that is, 7,074 donations were made in the summer, 6,541 donations in the fall, 7,482 donations in the winter and 6,203 donations in the spring.

This fact is tied to the campaigns carried out by the blood collection sectors. According to data provided by the institution, in the summer of 2014, 23 campaigns were developed, which resulted in the adhesion of 84 donors; in the fall, 21 campaigns were carried out with the participation of 203 volunteers; and in the spring there were 17 campaigns involving 130 blood donors.
In the winter months, however, it was not possible to reach an absolute number, since 9 campaigns were announced and only 51 donors made the donation. However, winter in Santa Catarina corresponds to school holidays and school games/spirit weeks, which always contribute immensely to storage maintenance.

According to the Manual with Guidelines for the Promotion of Voluntary Blood Donation (Manual de Orientações para a Promoção da Doação Voluntária de Sangue), the rate of adverse reactions varies according to the registration criteria, the donor profile and the characteristics of each service. Providing care to reactions and taking initiatives to minimize them deserve special attention. It is necessary, therefore, that blood banks have a guide to respond to reactions, and that there are medicines and equipment suitable for the care of donors who present such injuries ${ }^{(6)}$.

In this study there was a predominance of mild reactions, followed by moderate reactions and with very low prevalence of severe reactions. These findings diverge when compared to the results of another study ${ }^{(9)}$, which identified a predominance of severe reactions in relation to moderate reactions. A third study presents the incidence of $72.9 \%$ mild reactions, $15.3 \%$ moderate reactions and $2.5 \%$ serious reactions. The discrepancy in the percentage of the study is based on the characterization that 9.3\% of total donors suffered some type of phlebotomy accident, distinguishing them from the variable "adverse reaction"(17).

Although blood donation is considered a safe procedure, the data found in this study identifies the occurrence of adverse effects during donation, even if predominantly mild. However, it is necessary to know the effects to avoid or minimize them through previously known and planned care strategies.

\section{Study limitations}

Among the limitations of research, there is a need to expand studies regarding care provided to adverse reactions identified. Such information, because it is a retrospective study, cannot be identified, once this data is not included in the system that served as documentary basis for data collection. This implies the need to carry out prospective studies, which may contribute with information to write manuals to guide and better support the actions of Nursing in the face of these adverse events.

\section{Contributions to the Nursing field}

In the context of Nursing, the present study contributes to the advancement of knowledge and debate about nursing care needs aimed not only at blood receivers, but also at those who donate blood. The importance of Nursing performance was evidenced in different care follow-ups, and it is possible to emphasize how fundamental teamwork is, since it facilitates the rapid stabilization of donors, to guarantee a safe and quality care. It is hoped that the results of this investigation may support the development of prospective studies with this population, aiming to know more about the risk factors, to develop new strategies to reduce the adverse events of blood donation.

Thus, it is reinforced the importance of carrying out new studies and creating instruments that scientifically subsidize nursing practices in the blood collection rooms of national blood centers. 


\section{CONCLUSION}

Research allowed to characterize blood donors who presented adverse reactions to the donation, in a public hemocenter of the southern region of Brazil, as well as the adverse reactions presented by it. Donors are characterized as repeat donors, which had between one and three adverse events; they were female, single, with a complete average level of education, in the age range of 16 to 30 years old. The adversities of the studied hemocenter were identified in $3 \%$ of total donations of blood and had mild reactions as predominance.

The results of this study can alert to the need for change in the practice of hemotherapy regarding the development of standardized and safe actions in view of the occurrence of adverse reactions of blood donors. In this way, it becomes possible to alert to the need for changes in hemotherapy care practices.

\section{REFERENCES}

1. Pilger C, Menon MU, Mathias TAF. Socio-demographic and health characteristics of elderly individuals: support for health services. Rev Lat Am Enfermagem [Internet. 2011 [cited 2018 Oct 29];19(5):1230-8. Available from: http://dx.doi.org/10.1590/S0104-11692011000500022

2. Ministério da Saúde (BR), Secretaria de Gestão do Trabalho e da Educação na Saúde, Departamento de Gestão da Educação na Saúde. Técnico em Hemoterapia: livro texto. 1 ed. Brasília: Ministério da Saúde; 2013 [cited 2018 Nov 3]. 294 p. Available from: http://bvsms.saude. gov.br/bvs/publicacoes/tecnico_hemoterapia_livro_texto.pdf

3. Meena M, Jindal T. Complications associated with blood donations in a blood bank at an Indian Tertiary Care Hospital. J Clin Diagn Res [Internet]. 2014 [cited 2018 Oct 29];8(9):JC05-JC08. Available from: doi: 10.7860/JCDR/2014/8297.4812

4. Ministério da Saúde (BR), Gabinete do Ministro. Portaria no 158, de 04 de fevereiro de 2016. Aprova o Regulamento Técnico de Procedimentos Hemoterápicos [Internte]. Brasília: Ministério da Saúde; 2016 [cited 2018 Nov 3]. Available from: http://bvsms.saude.gov.br/ bvs/saudelegis/gm/2016/prt0158_04_02_2016.html

5. Conselho Federal de Enfermagem (COFEN). Resolução COFEN no 511/2016. Aprova a Norma Técnica que dispõe sobre a atuação de Enfermeiros e Técnicos de Enfermagem em Hemoterapia. Brasília: COFEN; 2016 [cited 2018 Nov 3]. [about 3 screens]. Available from: http:// www.cofen.gov.br/resolucao-cofen-no-05112016_39095.html

6. Ministério da Saúde (BR), Secretaria de Atenção a Saúde, Departamento de Atenção Especializada e Temática. Manual de Orientações para Promoção da Doação Voluntária de Sangue [Internet] 1 ed. Brasília: Ministério da Saúde, 2015. [cited 2018 Nov 3]. 152 p. Available from: http://bvsms.saude.gov.br/bvs/publicacoes/manual_orientacoes_promocao_doacao_voluntaria_sangue.pdf

7. Ministério da Saúde (BR), Agência Nacional de Vigilância Sanitária (ANVISA). Resolução de Diretoria Colegiada - RDC n 153, de 13 de junho de 2004: Determina o regulamento técnico para os procedimentos hemoterápicos, incluindo a coleta, o processamento, a testagem, o armazenamento, o transporte, o controle de qualidade e o uso humano de sangue, e seus componentes, obtidos do sangue venoso, 0 cordão umbilical, da placenta e da medula óssea [Internet]. Diário Oficial da União: República Federativa do Brasil; 2004 [cited 2018 Nov 3]. Jul 14, Seção 1: [about 15 screens]. Available from: http://www.sbpc.org.br/upload/noticias_gerais/320100416113458.pdf

8. Ministério da Saúde (BR), Gabinete do Ministro. Portaria no 2.712, de 12 de novembro de 2013. Aprova o Regulamento Técnico de Procedimentos Hemoterápicos [Internet]. Diário Oficial da União: República Federativa do Brasil; 2013.

9. Silva KFN, Barichello E, Mattia AL, Barbosa MH. Nursing care procedures in response to adverse events to blood donation. Text Context Enferm [Internet]. 2014 [cited 2018 Apr 12];23(3):688-695. Available from: http://dx.doi.org/10.1590/0104-07072014001360013

10. Ministério da Saúde (BR), Conselho Nacional de Saúde. Resolução n 466. Aprova as Diretrizes e Normas Regulamentadoras de Pesquisas Envolvendo Seres Humanos [Internet]. Diário Oficial da União: República Federativa do Brasil; 2012 [cited 2018 Nov 3]. Dez 12. Seção 1: [about 12 screens]. Available from: http://conselho.saude.gov.br/resolucoes/2012/reso466.pdf

11. Nassar SM, Wronscki VR, Ohira MS, et al. SEstatNet - Sistema Especialista para o Ensino de Estatística na Web [Internet]. Florianópolis (SC): UFSC; c1999-2015 [cited 2018 Nov 3]. Available fro: http://sestatnet.ufsc.br

12. Bermúdez HFC. Seguimiento a variables fisiológicas de donantes de sangre que presentaron reacciones adversas a la donación. Fundación Hematológica Colombia. Investig Andina [online] [Internet]. 2013 [cited 2018 Oct 29];15(27):838-46,. Available from: http://www.redalyc. org/pdf/2390/239028092009.pdf

13. Fundação Hemopa [Internet]. Belém: Hemocentro, 2018 [cited 2018 Nov 3]. Available from: http://www.hemopa.pa.gov.br/portal/index. php?option=com_content.

14. Santos FPA, Acioli S, Rodrigues VP, Machado JC, Souza MS, Couto TA. Nurse care practices in the family health strategy. Rev Bras Enferm [Internet] 2016 [cited 2018 Oct 29];69(6):1060-7. Available from: http://dx.doi.org/10.1590/0034-7167-2016-0273

15. Salaudeen AG, Odeh E. Knowledge and behavior towards voluntary blood donation among students of a tertiary institution in Nigeria. Niger J Clin Pract [Internet] 2011 [cited 2018 Oct 29];14(3):303-7. Available from: doi: 10.4103/1119-3077.86773

16. Zeiler T, Lander-Kox, Jutta ALT, T. Blood donation by elderly repeat blood donors. Transfus Med Hemother. [Internet] 2014 [cited 2018 Oct 29];41:242-250. Available from: https://doi.org/10.1159/000365401

17. Gupta S, Madan A, Dhar R, Borkar DB. A retrospective study of adverse events in blood donors from Navi Mumbai. Journal of Evolution of Medical and Dental Sciences [Internet]. 2013 [cited 2018 Oct 29]; 2(11):1575-80. Available from: https://www.jemds.com/data_pdf/1_seema\%20gupta.pdf 